\title{
Effect of Zinc and Iron Application on Yield Attributes, Available Nutrients Status and Nutrient Uptake of Finger Millet under Rainfed Condition
}

\author{
M. Vijayakumar ${ }^{*}$, R. Sivakumar ${ }^{2}$ and N. Tamilselvan ${ }^{3}$ \\ ${ }^{1}$ Soil Science, ${ }^{2}$ Crop Physiology and ${ }^{3}$ Agronomy, Regional Research Station, Tamil Nadu \\ Agricultural University, Paiyur, Krishnagiri, Tamil Nadu, India \\ *Corresponding author
}

\section{Ke y w o r ds \\ Zinc and iron, Yield attributes, Nutrients status, Nutrient uptake, Finger millet}

Article Info

Accepted:

26 April 2020

Available Online:

10 May 2020

\section{A B S T R A C T}

A field experiment was conducted during Kharif 2015 and 2016 for two consecutive years at Regional Research Station Farm, TNAU, Paiyur to study on effect of zinc and iron application on yield, available nutrient status and nutrient uptake of finger millet under rainfed condition. The experiment was laid out in a randomized block design with 10 treatments and replicated thrice. The pooled mean results revealed that an application of zinc and iron either enriched with FYM or foliar form along with macro nutrients (NPK) at different rates significantly influence the grain yield and nutrient $(\mathrm{N}, \mathrm{P} \& \mathrm{~K})$ uptake of finger millet. Higher grain $\left(2258 \mathrm{~kg} \mathrm{ha}^{-1}\right)$ and straw yield $\left(3692 \mathrm{~kg} \mathrm{ha}^{-1}\right)$ were obtained in the treatments of application of $\mathrm{RDF}\left(40: 20: 20 \mathrm{~N}: \mathrm{P}_{2} \mathrm{O}_{5}: \mathrm{K}_{2} \mathrm{O} \mathrm{kg} \mathrm{ha}^{-1}\right)$ along with $\mathrm{ZnSO}_{4}$ $(0.5 \%)+\mathrm{FeSO}_{4}(1 \%)+$ citric acid $(0.1 \%)$ spray twice at vegetative and flowering stages which was statistically on par with $\mathrm{NPK}+\mathrm{ZnSO}_{4}\left(12.5 \mathrm{~kg} \mathrm{ha}^{-1}\right)+\mathrm{FeSO}_{4}\left(25 \mathrm{~kg} \mathrm{ha}^{-1}\right)$ as EFYM. The lower grain yield $\left(1613 \mathrm{~kg} \mathrm{ha}^{-1}\right)$ was recorded with application of RDF alone. The total nutrient uptake such as $\mathrm{N}, \mathrm{P} \& \mathrm{~K}$ at harvest stage were higher with the treatment receiving $\mathrm{NPK}+\mathrm{ZnSO}_{4}(0.5 \%)+\mathrm{FeSO}_{4}(1 \%)+$ citric acid $(0.1 \%)$ spray twice at vegetative and flowering stages which was on par with $\mathrm{NPK}+\mathrm{ZnSO}_{4}\left(12.5 \mathrm{~kg} \mathrm{ha}^{-1}\right)+$ $\mathrm{FeSO}_{4}\left(25 \mathrm{~kg} \mathrm{ha}^{-1}\right)$ as EFYM. The higher iron uptake was recorded in the treatment receiving NPK along with $\mathrm{ZnSO}_{4}(0.5 \%)+\mathrm{FeSO}_{4}(1 \%)+$ citric acid $(0.1 \%)$ spray twice at vegetative and flowering stages which was statistically on par with $\mathrm{T}_{6}, \mathrm{~T}_{10}$ and $\mathrm{T}_{5}$ treatments. The higher nutrient uptake of zinc was recorded in the treatment receiving $\mathrm{NPK}+\mathrm{ZnSO}_{4}\left(12.5 \mathrm{~kg} \mathrm{ha}^{-1}\right)+\mathrm{FeSO}_{4}\left(25 \mathrm{~kg} \mathrm{ha}^{-1}\right)$ as EFYM which was statistically on par with $\mathrm{T}_{9}, \mathrm{~T}_{5}, \mathrm{~T}_{10}, \mathrm{~T}_{7}$ and $\mathrm{T}_{3}$ treatments.

\section{Introduction}

Finger millet is the third most important millet in India (locally called as Ragi) next to sorghum and pearl millet. Finger millet grown on marginal land provides a valuable resource in times of famine. Its grain tastes good and is nutritionally rich (compared to cassava, plantain, polished rice and maize meal) as it contains high levels of calcium, iron and manganese. The millet straw is also an important livestock feed, building material 
and fuel. Finger millet contains methionine, an essential amino acid lacking in the diets of hundreds of millions of the poor who rely mostly on starchy staples. The finger millet contains a low glycemic index and has no gluten, which makes it suitable for diabetics and people with digestive problems (Apoorva et al., 2010). Hence, finger millet considered as 'poor man' and also 'rich man crop'. Moreover, antioxidant properties, and phytochemicals make it easily and slowly digestible and help to control blood glucose levels in diabetes patients very efficiently. Finger millet can be grown both under rain fed and irrigated conditions. It is cultivated generally in rain fed conditions as a mixed crop with sorghum, pearl millet and a variety of oilseeds and pulses. But in Krishnagiri district, it can be grown under rain fed conditions. Ragi, being a $\mathrm{C}_{4}$ plant is an important grain crop and has a high production potential reaching up to 40 to 50 quintals $\mathrm{ha}^{-1}$ under optimum conditions. However, the yields achieved are far below its actual potential because it is predominantly grown under rain fed conditions.

The average productivity of state is considerably very low when compare with other states. This may be due to improper fertilization. Continuous use of inorganic nutrients may adversely affect the physico chemical properties of soil and thereby affect the crop yields. Globally, soils are deficient in essential micronutrients which affect both the quality and quantity of plant food. This thereby negatively affects a large portion of the world's population, which depends on plant based foods for essential minerals (Grotz and Guerinot, 2006). It is estimated that approximately $60 \%$ of the world's population is iron $(\mathrm{Fe})$ deficient and approximately $30 \%$ is zinc $(\mathrm{Zn})$ deficient in addition to other essential nutrient elements like calcium $(\mathrm{Ca})$, magnesium $(\mathrm{Mg})$ and copper $(\mathrm{Cu})$ deficiencies (Thacher et al., 2006).
It is found that most of the farmers are not applying micro nutrients for this crop. Finger millet requires considerable amount of zinc as well as iron for its growth and grain development. Application of a particular micronutrient might alter the concentration of other micronutrients there by changing their critical levels in plants. These interactions might be at the level of uptake, distribution or utilization (Imtiaz et al., 2003). Deficiency of micronutrients leads to reduction in number of effective tillers and improper grain filling. In order to sustain the yield and reduce the dependency on inorganic fertilizer use, conjunctive use of organic manures, bio fertilizers and fertilizers is very much essential (Shetty et al., 1993).

It is reported that during malting process, calcium and phosphorus content increases, whereas iron content decreases (Sangita and Saritha, 2000). Cakmak (2008), is highly effective and very practical way to maximize uptake and accumulation of zinc in whole wheat grain. Finger millet flour fortified with zinc oxide of the fortified mineral, as measured by in vitro, stimulated gastrointestinal digestion procedure and storage stability (Bhumika and Kalpana, 2010). Iron is an essential plant nutrient required for electron transport in photosynthesis. However, application of iron fertilizers may overcome its deficiency in soil and increase crop yields which will subsequently increase crop productivity and income of the farmers (Vikas et al., 2015).

Micronutrient deficiency, including $\mathrm{Zn}$, is increasing in most of the annual crops due to intensive cropping systems, use of modern high yielding cultivars, loss of organic matter in top soils by erosion, burning crop residues, liming acid soils, and use of inadequate rates in most cropping systems (Fageria et al., 2002). Zinc deficiency in crop plants is reported worldwide. According to Graham 
and Welch (1996), about 50\% of soils used for cereal production in the world contain low levels of plant-available $\mathrm{Zn}$, which reduce yield and nutritional quality of grains. Micronutrient deficiencies have been reported to be one of the main causes for yield plateau or even yield decline in intensified cropping systems (Katyal and Rattan, 2003). The rainfed soils of North Western zone is red sandy loam and non-calcareous and major areas is deficient in zinc. Finger millet is one of the predominant rainfed crop grown in this zone in more than 75,000 ha. Suitable nutrient management in respect of $\mathrm{Zn}$ and Fe nutrition has not yet been studied. Keeping all these view in addition to recommended dose of fertilizers, the experiment is proposed to find out the effect of zinc and iron on finger millet under rainfed condition.

\section{Materials and Methods}

The field experiments were conducted at Regional Research Station, Tamil Nadu Agricultural University, Paiyur at Krishnagiri of Tamil Nadu, Southern India on Inceptisol (Lithic Haplustept). The station is located in the North-west agro climatic zone of Tamil $\mathrm{Nadu}$ at $12.21^{\circ} \mathrm{N}$ Latitude and $78.18^{\circ} \mathrm{E}$ Longitude at an altitude of $490 \mathrm{~m}$ above MSL. The experiment was laid out in randomized block design and replicated thrice. It consist of ten treatments viz.,

$\mathrm{T}_{1}$-NPK alone (40:20:20 $\mathrm{kg} \mathrm{NPK} \mathrm{ha}^{-1}$ )-RDF, $\mathrm{T}_{2}-\mathrm{NPK}+\mathrm{ZnSO}_{4}\left(6.25 \mathrm{~kg} \mathrm{ha}^{-1}\right)$ as EFYM, $\mathrm{T}_{3}-\mathrm{NPK}+\mathrm{ZnSO}_{4}\left(12.5 \mathrm{~kg} \mathrm{ha}^{-1}\right)$ as EFYM, $\mathrm{T}_{4}-\mathrm{NPK}+\mathrm{FeSO}_{4}\left(25 \mathrm{~kg} \mathrm{ha}^{-1}\right)$ as EFYM,

$\mathrm{T}_{5^{-}} \mathrm{NPK}+\mathrm{ZnSO}_{4}\left(6.25 \mathrm{~kg} \mathrm{ha}^{-1}\right)+\mathrm{FeSO}_{4}(25$ $\left.\mathrm{kg} \mathrm{ha}^{-1}\right)$ as EFYM,

$\mathrm{T}_{6}-\mathrm{NPK}+\mathrm{ZnSO}_{4}\left(12.5 \mathrm{~kg} \mathrm{ha}^{-1}\right)+\mathrm{FeSO}_{4}(25$ $\left.\mathrm{kg} \mathrm{ha}^{-1}\right)$ as EFYM,

$\mathrm{T}_{7^{-}} \mathrm{NPK}+0.5 \% \quad \mathrm{ZnSO}_{4}$ spray twice (vegetative and flowering stages),

$\mathrm{T}_{8}-\mathrm{NPK}+1.0 \% \mathrm{FeSO}_{4}+0.1 \%$ Citric acid spray twice (vegetative and flowering stages), $\mathrm{T}_{9}-\mathrm{NPK}+0.5 \% \mathrm{ZnSO}_{4}+1.0 \% \mathrm{FeSO}_{4}+0.1 \%$
Citric acid spray twice (vegetative and flowering stages),

$\mathrm{T}_{10}$-NPK + TNAU MN mixture for millet (rainfed) crops @ $7.5 \mathrm{~kg} \mathrm{ha}^{-1}$ as EFYM.

As per the crop production guide, the recommended dose of fertilizers (40:20:20 kg $\mathrm{N}: \mathrm{P}_{2} \mathrm{O}_{5}: \mathrm{K}_{2} \mathrm{O}$ ha $^{-1}$ ) were applied as basal in the form of urea, single super phosphate and muriate of potash for all the treatments. The Zinc sulphate $\left(\mathrm{ZnSO}_{4}\right)$ and ferrous sulphate $\left(\mathrm{FeSO}_{4}\right)$ as Enriched Farm Yard Manure (EFYM) form applied as per the treatment structures. The soil of the experimental site was red sandy loam in nature which was low in organic carbon $4.4 \mathrm{~g} \mathrm{~kg}^{-1}$. The available nutrients status viz., soil nitrogen, phosphorus and potassium is 251, 19.5 and $350 \mathrm{~kg} \mathrm{ha}^{-1}$ with low, medium and high status respectively and with regards to available $\mathrm{Fe}$ and $\mathrm{Zn}$ content is 3.50 and $1.16 \mathrm{mg} \mathrm{kg}^{-1}$ respectively which was lower than the critical limit.

Post-harvest soil samples were also collected and analyzed for available N (Subbaiah and Asija, 1956), available P (Olsen et al., 1954) and available K (Hanwayand Heidal, 1952) status. Nitrogen content in plant samples was estimated by modified Microkjeldahl method after digested by diacid 5:2 $\left(\mathrm{H}_{2} \mathrm{SO}_{4}: \mathrm{HClO}_{4}\right)$ and expressed in per cent.

In the digested extract, phosphorus content was determined by Vanadomolybdate phosphoric yellow color method using Spectrophotometer at $420 \mathrm{~nm}$ and $\mathrm{P}$ content was expressed as per cent.

Potassium content in the triacid $(9: 2: 1$ of $\left.\mathrm{HNO}_{3}: \mathrm{H}_{2} \mathrm{SO}_{4}: \mathrm{HClO}_{4}\right)$ digest was determined using flame photometer (Piper, 1966) and expressed as per cent. The zinc and iron content in the triacid digest was estimated using Atomic absorption spectrophotometer (Lindsay and Norvell, 1978). 
The nutrient uptake was computed using the Formula

Total Nutrient uptake $=\quad$ Nutrient content $(\%) \times$ total dry matter yield $\left(\mathrm{kg} \mathrm{ha}^{-1}\right)$

[N, P, K, Fe \& Zn] $\left(\mathrm{kg} \mathrm{ha}^{-1}\right)$

100

\section{Results and Discussion}

\section{Growth and yield parameters}

The growth and yield attributes were significantly influenced with different nutrient application. Among the treatments application of NPK along with $\mathrm{ZnSO}_{4}(0.5 \%)+\mathrm{FeSO}_{4}$ $(1 \%)+$ citric acid $(0.1 \%)$ spray twice at vegetative and flowering stages was recorded higher plant height of $86.7 \mathrm{~cm}$ which was on par with $\mathrm{NPK}+\mathrm{ZnSO}_{4}\left(6.25 \mathrm{~kg} \mathrm{ha}^{-1}\right)+\mathrm{FeSO}_{4}$ (25 $\mathrm{kg} \mathrm{ha}^{-1}$ ) as EFYM and these were significantly better compared to all other treatments. Increase in plant height with increasing levels of nitrogen and foliar spray of $\mathrm{ZnSO}_{4}(0.5 \%)$ and $\mathrm{FeSO}_{4}(0.2 \%)$ reported by Sandhya Rani, et al., (2017). The maximum no. of tillers (6.95 nos.) was recorded in $\mathrm{NPK}+\mathrm{ZnSO}_{4}(0.5 \%)+\mathrm{FeSO}_{4}$ $(1 \%)+$ citric acid $(0.1 \%)$ spray twice which was on par with NPK + TNAU MN mixture for millet (rainfed) crops @ $7.5 \mathrm{~kg} \mathrm{ha}^{-1}$ as EFYM while, the minimum no. of tillers was recorded in recommended dose of NPK alone treatment.

Application of NPK along with $\mathrm{ZnSO}_{4}(0.5 \%)$ $+\mathrm{FeSO}_{4}(1.0 \%)+$ Citric acid $(0.1 \%)$ spray twice at vegetative and flowering stages recorded more no. of fingers (7.35 Nos.) which was statistically on par with NPK+ $\mathrm{ZnSO}_{4}\left(12.5 \mathrm{~kg} \mathrm{ha}^{-1}\right)+\mathrm{FeSO}_{4}\left(25 \mathrm{~kg} \mathrm{ha}^{-1}\right)$ as EFYM and NPK + TNAU MN mixture for millet (rainfed) crops @ $7.5 \mathrm{~kg} \mathrm{ha}^{-1}$ as EFYM. Similarly, the maximum length of fingers $(5.70 \mathrm{~cm})$ recorded in the treatment of NPK along with $\mathrm{ZnSO}_{4}(0.5 \%)+\mathrm{FeSO}_{4}(1.0 \%)+$ Citric acid $(0.1 \%)$ spray twice at vegetative and flowering stages which was statistically on par with $\mathrm{NPK}+\mathrm{ZnSO}_{4}\left(12.5 \mathrm{~kg} \mathrm{ha}^{-1}\right)+$ $\mathrm{FeSO}_{4}\left(25 \mathrm{~kg} \mathrm{ha}^{-1}\right)$ as EFYM.

There are significant differences among the treatments with respect to grain and straw yields. An application of NPK along with $\mathrm{ZnSO}_{4}(0.5 \%)+\mathrm{FeSO}_{4}(1 \%)+$ citric acid $(0.1 \%)$ spray twice at vegetative and flowering stages was recorded higher grain and straw yield of $2258 \mathrm{~kg} \mathrm{ha}^{-1}$ and $3692 \mathrm{~kg}$ $\mathrm{ha}^{-1}$ respectively which was statistically on par with $\mathrm{NPK}+\mathrm{ZnSO}_{4}\left(12.5 \mathrm{~kg} \mathrm{ha}^{-1}\right)+\mathrm{FeSO}_{4}$ $\left(25 \mathrm{~kg} \mathrm{ha}^{-1}\right)$ as EFYM while, the lower grain yield $\left(1613 \mathrm{~kg} \mathrm{ha}^{-1}\right)$ and straw yield $(2540 \mathrm{~kg}$ $\mathrm{ha}^{-1}$ ) respectively recorded with NPK alone treatment (Table 1). Similar increase in finger millet yield ( $3653 \mathrm{~kg} \mathrm{aha}^{-1}$ ) due to application of $\operatorname{RDF}\left(60: 40: 30 \mathrm{~N}: \mathrm{P}_{2} \mathrm{O}_{5}: \mathrm{K}_{2} \mathrm{O} \mathrm{kg} \mathrm{ha}{ }^{-1}\right)+$ foliar application of $\mathrm{FeSO}_{4} @ 0.5 \%$ twice at 30 and 60 DAS recorded by Ajay Kumar et al., (2020). Sandhya Rani et al., (2017) also reported higher grain and straw yield $(33.7 q$ $\mathrm{ha}^{-1}$ and $78.1 \mathrm{q} \mathrm{ha}{ }^{-1}$ respectively) of finger millet with application of $150 \% \mathrm{RDF}+$ Foliar spray of $\mathrm{ZnSO}_{4} @ 0.5 \%+\mathrm{FeSO} 4 @ 0.2 \%$. Srinivasarao et al., (2008) found that application of $\mathrm{Zn}, \mathrm{B}$, and sulfur (S) along with $\mathrm{N}$ and $\mathrm{P}$, enhanced finger millet grain yield $(56 \%)$, stover biomass $(44 \%)$, total biomass (48\%), and plant uptake of $\mathrm{Zn}(66 \%)$ and B (22\%) compared to the addition of $\mathrm{N}$ and $\mathrm{P}$ alone. Hegde and Gowda (1986) also claimed that incorporation of $\mathrm{N}$ fertilizer during seeding enhanced finger millet yield by $30 \%$ compared to broadcasted fertilizer. Synchronizing N supply with crop N demand is essential to maximize yield and $\mathrm{N}$ use efficiency. Maximum benefit-cost ratio was observed in NPK along with $\mathrm{ZnSO}_{4}(0.5 \%)+$ $\mathrm{FeSO}_{4}(1 \%)+$ citric acid $(0.1 \%)$ spray twice at vegetative and flowering stages (3.13) 
which was mainly due to higher grain yield and the less cost incurred on foliar spray of micronutrients. Hence, it was more profitable than rest of the treatments.

\section{Post-harvest soil available nutrients status}

Application of the major nutrients to finger millet alone does not necessarily provide better yields, rather the application of balanced nutrients is important as already noted above. The post-harvested soils were analyzed for available nitrogen, phosphorus, potassium, iron and zinc. The available nitrogen was varied from 224 to $242 \mathrm{~kg} \mathrm{ha}^{-1}$ (Fig. 1). The higher and lower values were recorded in the treatment of NPK + Ferrous sulphate $\left(25 \mathrm{~kg} \mathrm{ha}^{-1}\right)$ as EFYM and NPK + $\mathrm{ZnSO}_{4}\left(12.5 \mathrm{~kg} \mathrm{ha}^{-1}\right)+\mathrm{FeSO}_{4}\left(25 \mathrm{~kg} \mathrm{ha}^{-1}\right)$ as EFYM, respectively. Similar results were recorded (280 $\mathrm{kg} \mathrm{ha}^{-1}$ ) by Sandhya Rani, et al., (2017) by application of $\mathrm{RDF}+0.5 \%$ $\mathrm{ZnSO}_{4}+0.2 \% \mathrm{FeSO}_{4}$ in finger millet. The available $\mathrm{P}$ ranged between 17.3 and $20.6 \mathrm{~kg}$ $\mathrm{ha}^{-1}$ respectively in the treatments of NPK + $\mathrm{ZnSO}_{4}\left(12.5 \mathrm{~kg} \mathrm{ha}^{-1}\right)+\mathrm{FeSO}_{4}\left(25 \mathrm{~kg} \mathrm{ha}^{-1}\right)$ as EFYM and NPK + TNAU MN mixture for millet (rainfed) crops @ $7.5 \mathrm{~kg} \mathrm{ha}^{-1}$ as EFYM. With regards to available potassium it was varied from 297 to $324 \mathrm{~kg} \mathrm{ha}^{-1}$. The lower and higher values were recorded in treatment of $\mathrm{NPK}+0.5 \% \mathrm{ZnSO}_{4}$ spray twice at vegetative and flowering stages and NPK + Zinc sulphate $\left(6.25 \mathrm{~kg} \mathrm{ha}^{-1}\right)$ as EFYM, respectively. The available iron content was varied from 5.30 to $8.10 \mathrm{mg} \mathrm{kg}^{-1}$ respectively recorded in the treatments of NPK alone and $\mathrm{NPK}+\mathrm{FeSO}_{4}\left(25 \mathrm{~kg} \mathrm{ha}^{-1}\right)$ as EFYM and the available zinc content was varied from 1.10 to $1.66 \mathrm{mg} \mathrm{kg}^{-1}$ (Fig. 2). The higher and lower values recorded in the treatments of NPK + $\mathrm{ZnSO}_{4}\left(12.5 \mathrm{~kg} \mathrm{ha}^{-1}\right)$ as EFYM and NPK alone treatment, respectively. Application of optimum level of NPK fertilizers also helped in maintaining the $\mathrm{Zn}$ level in the soil below critical limit. This may be attributed to the fact that good amount of $\mathrm{Zn}$ contributed by single superphosphate and FYM, which contained variable amount of $\mathrm{Zn}$ in the range of $50-1000 \mathrm{mg} \mathrm{kg}^{-1}$ and $43-244 \mathrm{mg} \mathrm{kg}^{-1}$, respectively (Singh et al., 1999).

\section{Total nutrient uptake}

Nutrients uptake (N, P, K, Fe \& Zn) is vital in enhancing yield of finger millet. Considerable increase in uptake may increase the yield of finger millet. Uptake of any nutrient is the function of its content and dry matter production of the crop. Higher nutrient content in the produce and higher biomass production of finger millet might be the pertinent reason for higher uptake of nutrients. The total $\mathrm{N}$ uptake was higher $(80.5$ $\mathrm{kg} \mathrm{ha}{ }^{-1}$ ) with $\mathrm{NPK}+0.5 \% \mathrm{ZnSO}_{4}+1.0 \%$ $\mathrm{FeSO}_{4}+0.1 \%$ Citric acid spray twice at vegetative and flowering stages which was on par with $\mathrm{T}_{6} \& \mathrm{~T}_{10}$ treatments while, lower nitrogen uptake was recorded with application of NPK alone (Fig. 3).

The beneficial role of micronutrient in increasing the Cation Exchange Capacity of root helped in the increased absorption of nutrients from the soil. Further, the beneficial role of micronutrient in chlorophyll formation, regulating the auxin concentration and its stimulatory effect on most of physiological and metabolic processes of the plant might have helped the plants in absorption of greater amount of nitrogen from soil. The same findings observed by Mohammad et al., (2009) and Singh and Kumar (2011).

The phosphorus uptake varied from 12.9 to $19.5 \mathrm{~kg} \mathrm{ha}^{-1}$, the treatment that received NPK $+0.5 \% \mathrm{ZnSO}_{4}+1.0 \% \mathrm{FeSO}_{4}+0.1 \%$ Citric acid spray twice at vegetative and flowering stages recorded higher value which was on par with $\mathrm{NPK}+\mathrm{ZnSO}_{4}\left(12.5 \mathrm{~kg} \mathrm{ha}^{-1}\right)+$ $\mathrm{FeSO}_{4}\left(25 \mathrm{~kg} \mathrm{ha}^{-1}\right)$ as EFYM and the lower P uptake was recorded with the NPK alone treatment. The improved nutrient uptake was 
attributed to the positive influence of nutrients on protein and nucleic acid synthesis which was occurrence with findings of Gondar et al., (2006).

The $\mathrm{K}$ uptake pattern depends on plant biomass and nutrient concentration in plant part and the crops shoot uptake was more than root with respect $\mathrm{K}$ nutrient. The potassium uptake ranged between 70 and $108.6 \mathrm{~kg} \mathrm{ha}^{-1}$, among the treatments NPK along with $0.5 \%$ $\mathrm{ZnSO}_{4}+1.0 \% \mathrm{FeSO}_{4}+0.1 \%$ Citric acid spray twice at vegetative and flowering stages recorded higher $\mathrm{K}$ uptake which was statistically on par with $\mathrm{NPK}+\mathrm{ZnSO}_{4}(12.5$ $\left.\mathrm{kg} \mathrm{ha}^{-1}\right)+\mathrm{FeSO}_{4}\left(25 \mathrm{~kg} \mathrm{ha}^{-1}\right)$ as EFYM and the lower $\mathrm{K}$ uptake was recorded with NPK alone treatment (Fig. 3). Similar results of improved dry matter production and nutrient uptake in finger millet with foliar application of $\mathrm{FeSO}_{4} @ 0.5 \%$ twice at 30 and 60 DAS was earlier reported by Ajay Kumar et al., (2020).

Table.1 Biometric observations, yield attributes and yield of finger millet under rainfed condition (Pooled Analysis)

\begin{tabular}{|c|c|c|c|c|c|c|c|}
\hline Treatments & $\begin{array}{l}\text { Plant Height } \\
\text { (cm) }\end{array}$ & $\begin{array}{l}\text { No. of } \\
\text { Tillers }\end{array}$ & $\begin{array}{l}\text { No. of } \\
\text { fingers }\end{array}$ & $\begin{array}{l}\text { Length of } \\
\text { fingers } \\
\text { (cm) }\end{array}$ & $\begin{array}{c}\text { Grain } \\
\text { yield } \\
\left(\mathrm{kg} \mathrm{ha}^{-1}\right)\end{array}$ & $\begin{array}{c}\text { Straw } \\
\text { yield } \\
\left(\mathrm{kg} \mathrm{ha}^{-1}\right)\end{array}$ & $\begin{array}{l}\text { B:C } \\
\text { ratio }\end{array}$ \\
\hline $\mathbf{T}_{1}$ & 66.5 & 3.70 & 5.65 & 4.60 & 1613 & 2540 & 2.18 \\
\hline $\mathbf{T}_{1}$ & 78.0 & 4.85 & 6.05 & 4.70 & 1727 & 2580 & 2.38 \\
\hline $\mathbf{T}_{1}$ & 79.1 & 4.80 & 6.40 & 4.95 & 1881 & 3075 & 2.48 \\
\hline $\mathbf{T}_{1}$ & 74.0 & 4.65 & 6.75 & 5.25 & 1942 & 3133 & 2.50 \\
\hline $\mathbf{T}_{1}$ & 81.2 & 5.40 & 6.55 & 4.95 & 2043 & 3311 & 2.88 \\
\hline $\mathbf{T}_{1}$ & 74.9 & 5.50 & 7.05 & 5.50 & 2139 & 3553 & 2.78 \\
\hline $\mathbf{T}_{1}$ & 76.5 & 5.30 & 6.65 & 5.15 & 2033 & 3290 & 2.73 \\
\hline $\mathbf{T}_{1}$ & 77.6 & 5.40 & 6.45 & 4.95 & 1893 & 3010 & 2.55 \\
\hline $\mathbf{T}_{1}$ & 86.7 & 6.95 & 7.35 & 5.70 & 2258 & 3692 & 3.13 \\
\hline $\mathbf{T}_{1}$ & 78.8 & 6.45 & 6.95 & 5.20 & 2040 & 3320 & 3.02 \\
\hline S. Ed & 3.13 & 0.238 & 0.234 & 0.197 & 84.3 & 158 & \\
\hline C.D $(p=0.05)$ & 6.57 & 0.504 & 0.494 & 0.418 & 176 & 331 & \\
\hline
\end{tabular}


Fig.1 Effect of zinc and iron application on post-harvest soils of major nutrient status (N, P \& K) in finger millet under rainfed condition

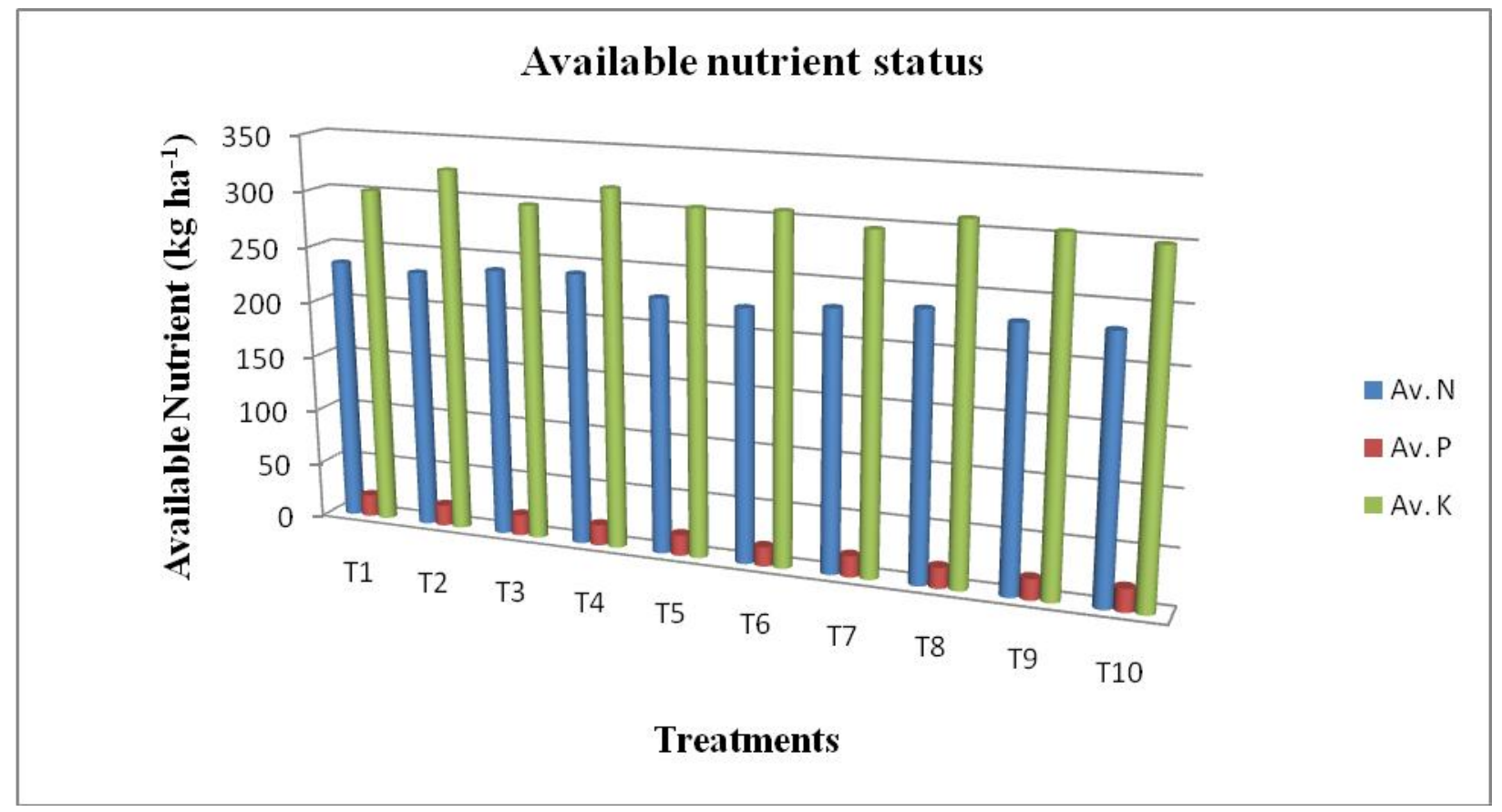

Fig.2 Effect of zinc and iron application on post-harvest soils of micronutrient status (Fe \& $\mathrm{Zn})$ in finger millet under rainfed condition

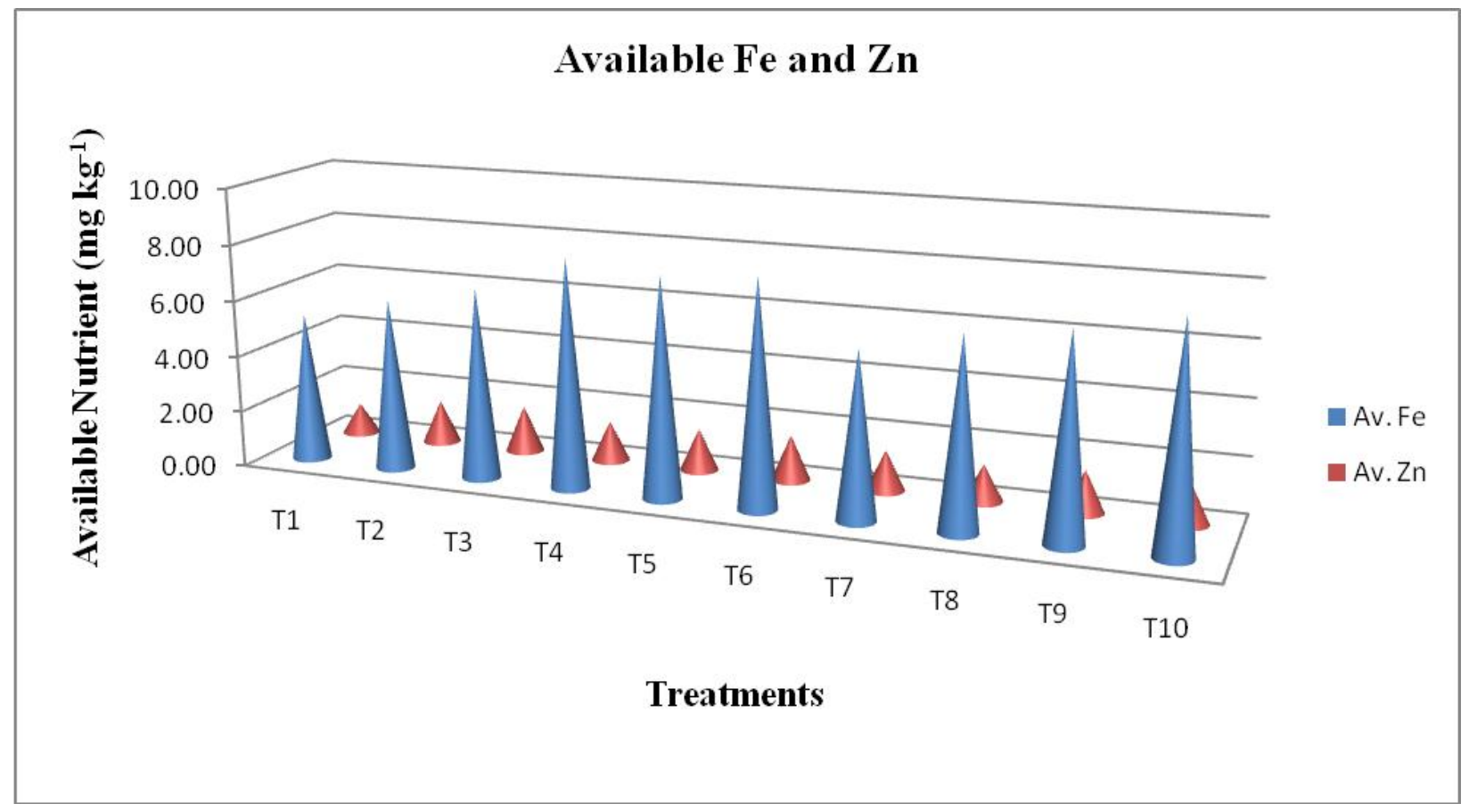


Fig.3 Effect of zinc and iron application on major nutrient uptake of finger millet under rainfed condition

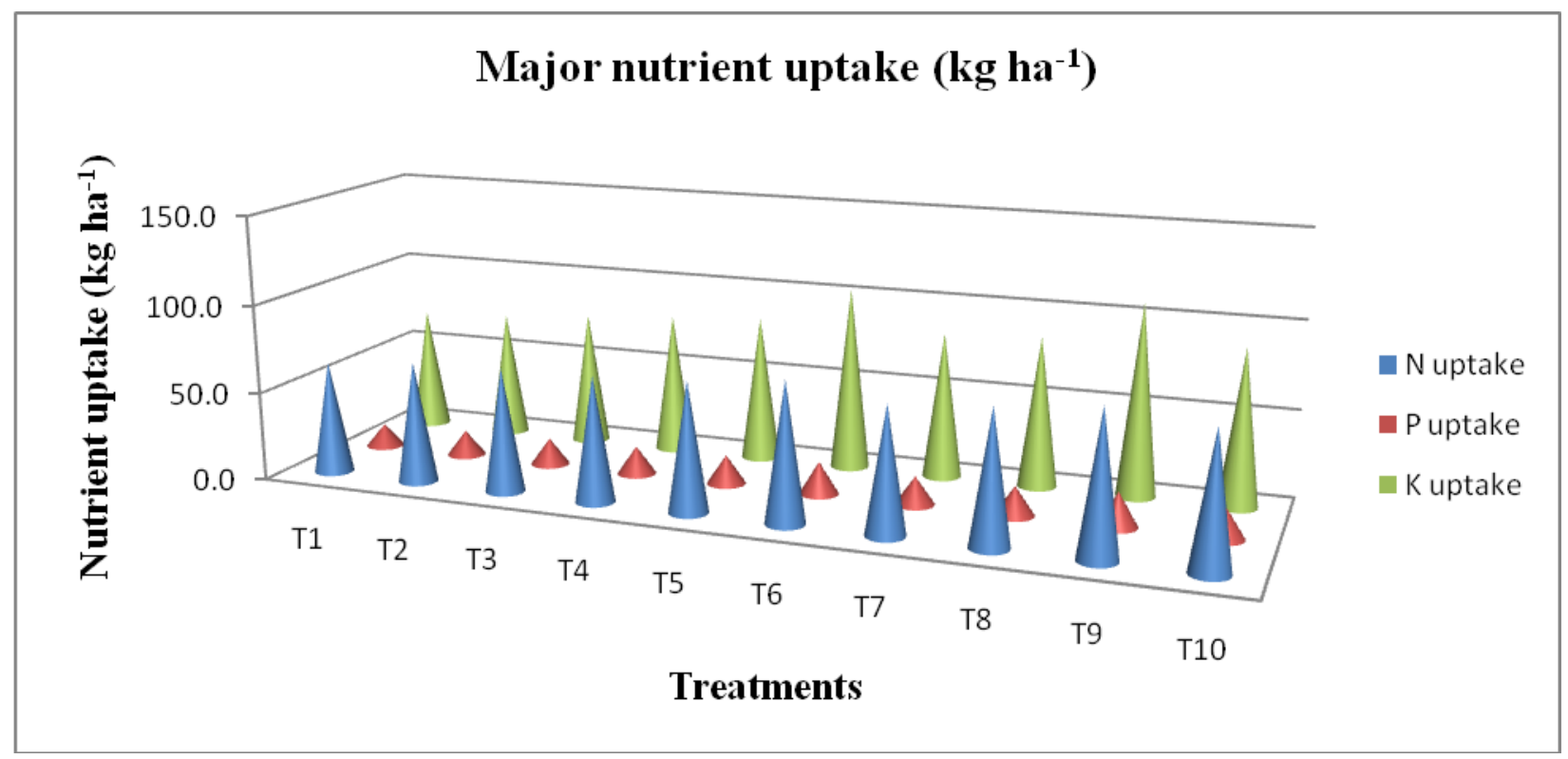

Fig.4 Effect of zinc and iron application on Fe and Zn uptake of finger millet under rainfed condition

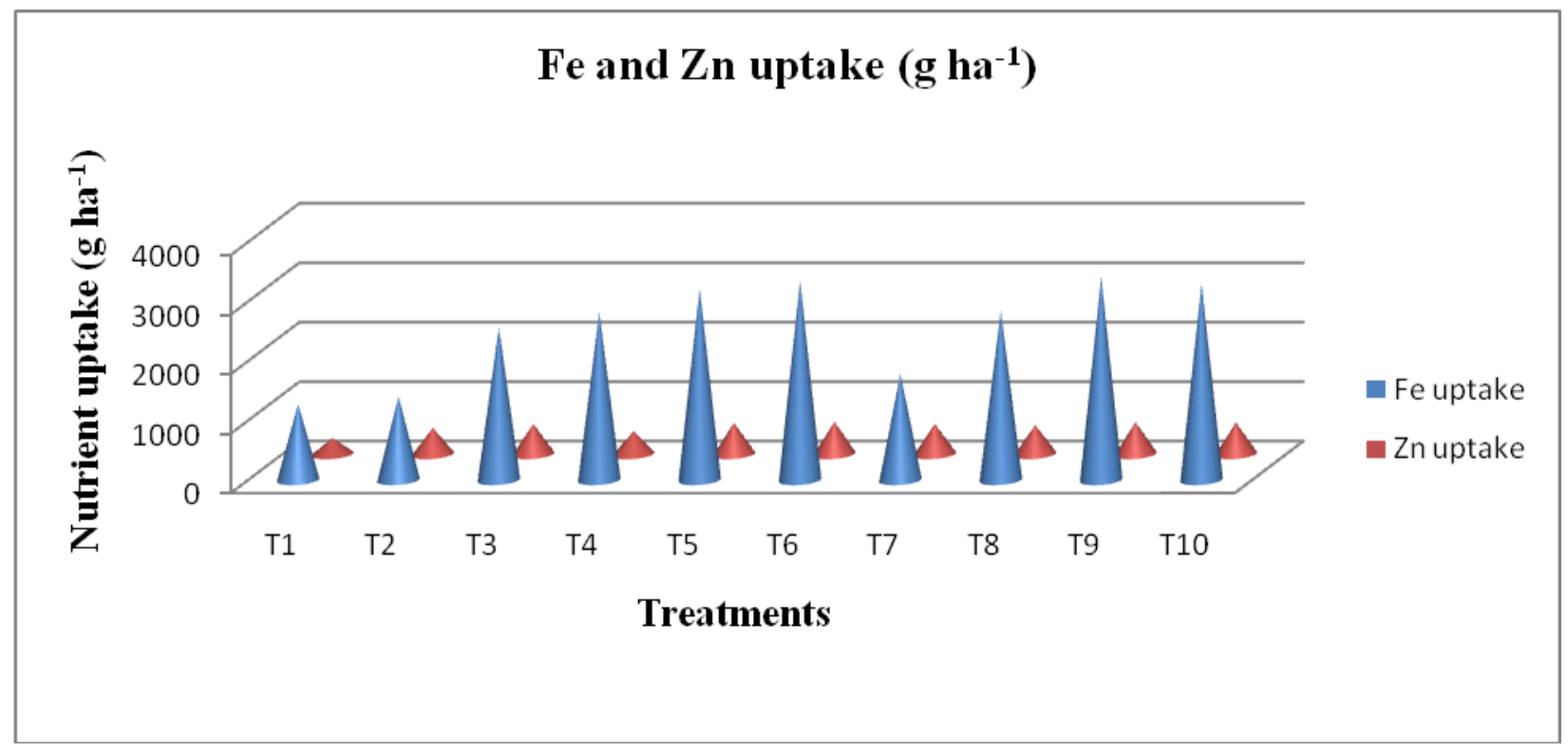

Higher iron uptake $\left(3415 \mathrm{~g} \mathrm{ha}^{-1}\right)$ was recorded in the treatment receiving $\mathrm{NPK}+0.5 \%$ $\mathrm{ZnSO}_{4}+1.0 \% \mathrm{FeSO}_{4}+0.1 \%$ Citric acid spray twice at vegetative and flowering stages which was on par with $\mathrm{T}_{6}, \mathrm{~T}_{10} \& \mathrm{~T}_{5}$ treatments and lower value (1285 $\mathrm{g} \mathrm{ha}^{-1}$ ) was obtained with NPK alone treatment. At harvest stage the $\mathrm{Zn}$ uptake was worked out and the higher value $\left(545 \mathrm{~kg} \mathrm{ha}^{-1}\right)$ obtained with $\mathrm{NPK}+$ $\mathrm{ZnSO}_{4}\left(12.5 \mathrm{~kg} \mathrm{ha}^{-1}\right)+\mathrm{FeSO}_{4}\left(25 \mathrm{~kg} \mathrm{ha}^{-1}\right)$ as EFYM which was on par with $\mathrm{T}_{9}, \mathrm{~T}_{10}, \mathrm{~T}_{5}, \mathrm{~T}_{3}$ $\& \mathrm{~T}_{7}$ treatments while, lower $\mathrm{Zn}$ uptake (272 
$\mathrm{g} \mathrm{ha}^{-1}$ ) was recorded with application of NPK alone treatment (Fig. 4). Higher biomass producing crops secreted higher amount of organic substances in the soil, which act as a chelating agent for the enhancement of micronutrients (Dotaniya et al., 2013). Decayed plants parts released the micro nutrient carrying organic molecules, and accelerate the micronutrient uptake by plant (Dotaniya and Datta, 2013).

In conclusion, foliar application of zinc, iron and citric acid brought about an improvement in yield and nutrients uptake of finger millet. Higher grain $\left(2258 \mathrm{~kg} \mathrm{ha}^{-1}\right)$ and straw yield (3692 $\mathrm{kg} \mathrm{ha}^{-1}$ ) were obtained in the treatments of application of $\mathrm{RDF}\left(40: 20: 20 \mathrm{~N}: \mathrm{P}_{2} \mathrm{O}_{5}: \mathrm{K}_{2} \mathrm{O}\right.$ $\left.\mathrm{kg} \mathrm{ha}{ }^{-1}\right)$ along with $\mathrm{ZnSO}_{4}(0.5 \%)+\mathrm{FeSO}_{4}$ $(1 \%)+$ citric acid $(0.1 \%)$ spray twice at vegetative and flowering stages which was statistically on par with $\mathrm{NPK}+\mathrm{ZnSO}_{4}(12.5$ $\left.\mathrm{kg} \mathrm{ha}^{-1}\right)+\mathrm{FeSO}_{4}\left(25 \mathrm{~kg} \mathrm{ha}^{-1}\right)$ as EFYM. The total nutrient uptake such as $\mathrm{N}, \mathrm{P}, \mathrm{K} \& \mathrm{Fe}$ at harvest stage were higher with the treatment receiving $\mathrm{NPK}+\mathrm{ZnSO}_{4}(0.5 \%)+\mathrm{FeSO}_{4}$ $(1 \%)+$ citric acid $(0.1 \%)$ spray twice at vegetative and flowering stages which was on par with $\mathrm{NPK}+\mathrm{ZnSO}_{4}\left(12.5 \mathrm{~kg} \mathrm{ha}^{-1}\right)+$ $\mathrm{FeSO}_{4}\left(25 \mathrm{~kg} \mathrm{ha}^{-1}\right)$ as EFYM. The higher nutrient uptake of zinc was recorded in the treatment receiving $\mathrm{NPK}+\mathrm{ZnSO}_{4}(12.5 \mathrm{~kg}$ $\left.\mathrm{ha}^{-1}\right)+\mathrm{FeSO}_{4}\left(25 \mathrm{~kg} \mathrm{ha}^{-1}\right)$ as EFYM which was statistically on par with $\mathrm{T}_{9}, \mathrm{~T}_{5}, \mathrm{~T}_{10}, \mathrm{~T}_{7}$ and $\mathrm{T}_{3}$ treatments.

\section{References}

Ajay Kumar, E., Surekha K., Bhanu Rekha K. and Harish Kumar Sharma S. 2020. Effect of Various Sources of Zinc and Iron on Grain Yield, Nutrient Uptake and Quality Parameters of Finger Millet (Eleusine coracana L.). International Research Journal of Pure \& Applied Chemistry. 21(2): 46-55.

Apoorva, K. B., Prakash S. S., Rajesh N.L. and Nandini B. 2010. STCR Approach for
Optimizing Integrated Plant Nutrient Supply on Growth, Yield and Economics of Finger Millet (Eleusine coracana (L.) Garten.). European Journal of Biological Sciences. 4 (1): 19-27.

Bhumika, T. and Kalpana P. 2010. Finger millet flour as a vehicle for fortification with zinc. Journal of Trace Elements in Medicine and Biology. 24(1): 46-51.

Cakmak, I. 2008. Enrichment of cereal grains with Zinc Agronomic or genetic bio fortification. Plant and Soil. 302(1-2): 1-17.

Dotaniya, M. L., Meena H. M., Lata M. and Kumar K. 2013. Role of phytosiderophores in iron uptake by plants. Agricultural Science Digest. 33(1): 73-76.

Dotaniya, M.L. and Datta S.C. 2013. Impact of bagasse and press mud on availability and fixation capacity of phosphorus in an Inceptisol of north India. Sugar Technology. DOI 10.1007/s12355-0130264-3.

Fageria, N. K., Baligar, V.C. and Clark R. B. 2002. Micronutrients in crop production. Advances in Agronomy, New York, v. 77, p. 189-272.

Graham, R. D. and Welch R. M. 1996. Breeding for staple- food crops with high micronutrient density. Agricultural Strategies for Micronutrients Working Paper No. 3. Washington, DC: International Food Policy Research Institute, 1-72.

Gondar, D., Lopez F. S., Antelo J. M. and Arce F. 2006. Cadmium, lead and copper binding to humic acid and fulvic acid extracted from an ombrotrophic peat bog. Geoderma.13:196-203.

Grotz, N. and Guerinot M. L. 2006. Molecular aspects of $\mathrm{Cu}, \mathrm{Fe}$ and $\mathrm{Zn}$ homeostasis in plants. Biochimica et Biophysica Acta. 1763: 595-608.

Hanway, J.J. and Heidal H. 1952. Soilanalysis methods asused in Iowa state college soil testing laboratory. Lowa State College of Agriculture Bulletin, 57: 1-31.

Hegde, B.R. and Gowda L. 1986. Cropping systems and production technology for small millets in India. In Proceedings of the First International Small Millets Workshop, Bangalore, India, 29 October - 2 November. pp. 209-236. 
Imtiaz, M., Alloway B. J., Shah K. H., Siddiqui S. H., Memon M. Y., Aslam M. and Khan P. 2003. Zinc nutrition of wheat II: Interaction of zinc with other trace elements. Asian Journal of Plant Sciences 2: 156-160.

Katyal, J.C. and Rattan R. K. 2003. Secondary and micronutrients: Research gaps and future needs. Fertility News 48 (4): 9-14.

Lindsay, W. L. and Norvell W. A. 1978. Development of DTPA soil test for zinc, iron, manganese and copper. Soil Science Society of America Journal. 43: 421-428.

Mohammad, R., Pahlavan R. and Mohammad P. 2009. Response of wheat plants to zinc, iron and Manganese application and uptake and concentration of zinc, iron and manganese in wheat grains. Communication in Soil Science and Plant Analysis. 40: 1322-1332.

Olsen S.R., Cole C.V., Watanabe F.S. and Dean L. 1954. 'Estimation of available phosphorus in soils by extraction with sodium bicarbonate'. U.S.D.A. Circ. 939. (U.S. Govt. Printing Office: Washington, DC).

Piper CS. 1966. Soil and plant analysis. Hans Publishers, Bombay. 137-153.

Sandhya Rani, Y., Triveni U, Patro T. S. S. K. and Anuradha N. 2017. Effect of nutrient management on yield and quality of finger millet. International Journal of Chemical Studies. 5(6): 1211-1216.

Sangita, K. and Sarita S. 2000. Nutritive value of malted flours of finger millet genotypes and their use in the preparation of burfi. Journal of Food Science Technology. 37(4): 419122.
Shetty,Y.V., Sheshadri T., Vasuki N. and Gajanan G.N. 1993. Effect of organic and Inorganic nutrient Sources on yield of Ragi and groundnut under rainfed condition. Annual Report, 40: 45-46.

Singh, N.P., Sachan R.S., Pandey P.C. and Bisht P.S. 1999. Effect of decade long fertilizer and manure application on soil fertility and productivity of Rice-Wheat system in a Mollisol. Journal of the Indian Society of Soil Science. 47(1): 72-80.

Singh, S. and Kumar A. 2011. Effect of micronutrient on yield, quality and nutrient uptake by wheat in alluvial soil. Annals of Plant and Soil Research. 13:84-86.

Srinivasarao, C., Wani S. P., Sahrawat K. L., Rego T. J. and Pardhasaradhi G. 2008. Zinc, boron and sulphur deficiencies are holding back the potential of rainfed crops in semi-arid India: Experiences from participatory watershed management. International Journal of Plant Production. 2: 89-99.

Subbiah, B.V. andAsija G.L. 1956. A rapid procedure for estimation of available nitrogen in soils. Current Science25:259260.

Thacher, T. D., Fischer P. R., Strand M. A. and Pettifor J. M. 2006. Nutritional rickets around the world: Causes and future directions. Annals of Tropical Paediatrics. 26: $1-16$.

Vikash, K., Dinesh K., Singh Y.V. and Rishi R. 2015. Effect of Iron fertilization on drymatter production, yield and economics of aerobic rice (Oryza sativa L.). Indian Journal of Agronomy. 60(4): 547-553.

\section{How to cite this article:}

Vijayakumar, M., R. Sivakumar and Tamilselvan, N. 2020. Effect of Zinc and Iron Application on Yield Attributes, Available Nutrients Status and Nutrient Uptake of Finger Millet under Rainfed Condition. Int.J.Curr.Microbiol.App.Sci. 9(05): 3237-3246. doi: https://doi.org/10.20546/ijcmas.2020.905.384 